\title{
Redesigning biodiversity conservation projects for climate change: examples from the field
}

\author{
Karen A. Poiani • Rebecca L. Goldman • Jennifer Hobson • \\ Jonathan M. Hoekstra $\cdot$ Kara S. Nelson
}

Received: 22 April 2010/ Accepted: 18 November 2010/Published online: 8 December 2010

(C) The Author(s) 2010. This article is published with open access at Springerlink.com

\begin{abstract}
Few conservation projects consider climate impacts or have a process for developing adaptation strategies. To advance climate adaptation for biodiversity conservation, we tested a step-by-step approach to developing adaptation strategies with 20 projects from diverse geographies. Project teams assessed likely climate impacts using historical climate data, future climate predictions, expert input, and scientific literature. They then developed adaptation strategies that considered ecosystems and species of concern, project goals, climate impacts, and indicators of progress. Project teams identified 176 likely climate impacts and developed adaptation strategies to address 42 of these impacts. The most common impacts were to habitat quantity or quality, and to hydrologic regimes. Nearly half of expected impacts were temperature-mediated. Twelve projects indicated that the project focus, either focal ecosystems and species or project boundaries, need to change as a result of considering climate impacts. More than half of the adaptation strategies were resistance strategies aimed at preserving the status quo. The rest aimed to make ecosystems and species more resilient in the face of expected changes. All projects altered strategies in some way, either by adding new actions, or by adjusting existing
\end{abstract}

Electronic supplementary material The online version of this article (doi:10.1007/s10531-010-9954-2) contains supplementary material, which is available to authorized users.

K. A. Poiani $(\bowtie)$

The Nature Conservancy, 322 Eighth Ave., 16th Floor, New York, NY 10001, USA

e-mail: kpoiani@tnc.org

R. L. Goldman

The Nature Conservancy, Arlington, VA 22203, USA

Present Address:

R. L. Goldman

Inter-American Development Bank, Washington, DC 20577, USA

J. Hobson

Colorado State University, Fort Collins, CO 80521, USA

J. M. Hoekstra · K. S. Nelson

The Nature Conservancy, Seattle, WA 98101, USA 
actions. Habitat restoration and enactment of policies and regulations were the most frequently prescribed, though every adaptation strategy required a unique combination of actions. While the effectiveness of these adaptation strategies remains to be evaluated, the application of consistent guidance has yielded important early lessons about how, when, and how often conservation projects may need to be modified to adapt to climate change.

Keywords Biodiversity - Climate adaptation - Climate change - Climate impacts . Conservation planning $\cdot$ Conservation strategies $\cdot$ Global warming $\cdot$ Resilience

Sea-level rise

\author{
Abbreviations \\ CMP Conservation Measures Partnership \\ IPCC Intergovernmental Panel on Climate Change \\ TNC The Nature Conservancy
}

\title{
Introduction
}

Climate change is a significant threat to biodiversity, affecting the world's ecosystems and species. Impacts are already occurring, from shifting species distributions to altered environmental conditions, and are resulting from changing temperatures, more frequent extreme events, and exacerbation of existing threats (Tompkins and Adger 2004; Welch 2005; Parmesan 2006; Parry et al. 2007). Integrating climate change into conservation strategies is vital if biodiversity is to be protected in the long term (Hannah et al. 2002a; Welch 2005; Araujo and Rahbek 2006; Heller and Zavaleta 2009). This is especially true in the context of the many other current threats to natural systems (Peters and Myers 1991; Sala et al. 2000; Root and Schneider 2006; Orr 2008). Numerous publications have outlined climate adaptation strategies for biodiversity (Hannah et al. 2002a, b; Scott and Lemieux 2005; Vos et al. 2008; Dunwiddie et al. 2009; Lawler et al. 2009; Hunter et al. 2010). Examples in the literature include reducing existing threats, habitat restoration, increasing connectivity, changing conservation priorities, and moving species to more suitable habitats (Hulme 2005; Kareiva et al. 2008; Mawdsley et al. 2009; Krosby et al. 2010).

Yet despite the widely touted importance of climate impacts, few conservation projects actually consider climate change or have a process for developing climate-adapted strategies (Hannah et al. 2002b; Bierwagen et al. 2008; McClanahan et al. 2008). Practitioners face obstacles such as cost, institutional inertia, limited regional and local predictions, and uncertainty (Galatowitsch et al. 2009; Lawler 2009; Mawdsley et al. 2009). For example, project managers in The Nature Conservancy (TNC) typically develop conservation strategies based on current biodiversity, current land cover and landownership maps, and threats analyses projecting out 10 years. Climate change, if considered at all, is usually regarded as an abstract threat without articulating the mechanism of impact and without following those impacts through to building appropriate strategies and actions.

To address the gap in incorporating climate considerations into biodiversity conservation efforts, we worked with 20 conservation projects to apply a common process for developing climate adaptation strategies. We assumed that a coordinated effort with a number of projects would advance our thinking and help establish working guidelines more quickly than an individual, piecemeal approach. To our knowledge, there has been no other 
effort to develop adaptation strategies for a group of existing biodiversity conservation projects simultaneously and using the same general process.

The effort to develop adaptation strategies for 20 conservation projects was viewed as a learning experiment that would shed light on a number of important questions: (1) what are the key steps needed for addressing climate change impacts in conservation strategies? (2) How does incorporating climate change alter the focus of a project (i.e., the focal ecosystems and species and project boundary)? (3) How do existing conservation strategies change when we incorporate future climate impacts? (4) How do we make consideration of climate impacts commonplace in our conservation efforts? Here we report how climate change is expected to affect ecosystems and species in the conservation projects analyzed, and discuss how conservation strategies were modified to adapt to those impacts. The ultimate goal in sharing these early results is to help make conservation projects and their associated outcomes more robust in an uncertain future as quickly as possible.

\section{Methods}

Conservation projects were self nominated from across TNC's state and country conservation programs following a general call for proposals. Half of the final 20 projects were from the United States and half from other countries where TNC operates (Table 1). Final projects selected were required to have an initial conservation plan and strategies that did not adequately consider the potential impacts from climate change.

Project teams were comprised of experienced conservation practitioners and scientists. Team members consisted of various TNC staff and partners from federal or governmental agencies, other non-governmental organizations, and academia. Each project had at least one scientist with an advanced degree (masters or Ph.D.) as part of the core team or as a close advisor.

Project directors and scientists for the 20 conservation projects identified the most likely impacts of climate change on the ecosystems and species of conservation concern using historical data on climate trends over the last 50 years, projections of future climate change taken from IPCC Global Circulation Models, expert input, and the general scientific literature. Project teams used Climate Wizard (or other climate analysis tools) to explore potential changes in temperature and precipitation for their project areas (Girvetz et al. 2009). They then drew on local expertise and experience to predict specific ecological impacts that are likely to follow from climate change. Teams were asked to narrow their initial ideas to no more than eight impacts and to prioritize those they believed would have the most significant implications for their conservation project to ensure that adaptation strategies focused on what was most critical. Research on climate change and likely impacts was completed over a period of 7 months.

Following this initial 7-month research period, we brought all 20 teams together for an in-person workshop (September 2009) to develop adaptation strategies. At the workshop, project teams used a step-by-step approach to evaluate potential climate impacts and to determine whether and how their original project strategies should be modified (Table 2). The strategy development process was based on the Open Standards for the Practice of Conservation (CMP 2007), and required an assessment of ecosystems and species of conservation concern, project goals, threats, strategies to reduce threats, and indicators and measures of progress. However, at the workshop, the process was applied with explicit attention to potential climate impacts and using a 50-year time horizon. These same methods were applied to all 20 projects at all spatial scales (Table 1). This overall process 
Table 1 Name, location, size and ecological focus of 20 conservation projects that developed climate adaptation strategies

\begin{tabular}{|c|c|c|}
\hline Project & $\begin{array}{l}\text { Approximate } \\
\text { size (hectares) }\end{array}$ & Primary ecosystems \\
\hline $\begin{array}{l}\text { Altamaha-Ogeechee Estuarine } \\
\text { Complex, USA }\end{array}$ & 412,862 & $\begin{array}{l}\text { Salt marsh; sandy beaches; oyster reefs; tidal creeks } \\
\text { and tributaries }\end{array}$ \\
\hline $\begin{array}{l}\text { Atitlán Watershed Multiple Use } \\
\text { Reserve, Guatemala }\end{array}$ & 124,722 & $\begin{array}{l}\text { Broad-leaf forest; xerophytic vegetation; lake } \\
\text { aquatic systems }\end{array}$ \\
\hline Atlantic Forest, Brazil & 80 million & Araucaria forest; evergreen forest \\
\hline $\begin{array}{l}\text { Central Appalachian Integrated } \\
\text { Landscape, USA }\end{array}$ & 13 million & $\begin{array}{l}\text { Central Appalachian forest matrix; freshwater } \\
\text { headwater and medium sized streams; cave and } \\
\text { karst; endemic patch habitats }\end{array}$ \\
\hline $\begin{array}{l}\text { Chongming Dongtan Estuary, } \\
\text { China }\end{array}$ & 24,000 & Intertidal flats \\
\hline $\begin{array}{l}\text { Coastal Cordillera Dry Forests, } \\
\text { Ecuador }\end{array}$ & 400,000 & $\begin{array}{l}\text { Seasonal evergreen, deciduous and semi-deciduous } \\
\text { forest; freshwater ecosystems; mangrove }\end{array}$ \\
\hline Dugout Ranch, Utah, USA & 135,000 & $\begin{array}{l}\text { Low and mid elevation: semi-desert shrubland; high } \\
\text { elevation: piñon-juniper with mixed-conifer }\end{array}$ \\
\hline Edge of Ice, Massachusetts, USA & 155,000 & $\begin{array}{l}\text { Coastal xeric complex; insular morainal woodlands; } \\
\text { salt ponds; bays and associated wetlands; forest } \\
\text { blocks; coastal plain ponds; Taunton River and } \\
\text { tributaries; large swamps }\end{array}$ \\
\hline $\begin{array}{l}\text { Lakes Huron and Ontario, USA } \\
\text { and Canada }\end{array}$ & 19.8 million & Coastal wetlands; nearshore aquatic \\
\hline $\begin{array}{l}\text { Gulf of California and Coastal } \\
\text { Watersheds, Mexico }\end{array}$ & 85 million & $\begin{array}{l}\text { River systems; groundwater dependent wetlands; } \\
\text { estuaries; mangroves; shoreline; rocky reef; blue } \\
\text { water systems }\end{array}$ \\
\hline $\begin{array}{l}\text { Hudson River Estuary, } \\
\text { New York, USA }\end{array}$ & 1.4 million & Partially mixed estuary; tidal river \\
\hline $\begin{array}{l}\text { Mediterranean Baja California, } \\
\text { Mexico }\end{array}$ & 136,000 & $\begin{array}{l}\text { Salt marsh; beaches; riparian ecoystems; coastal } \\
\text { scrub; bays; hypersaline lagoons; coastal-ocean; } \\
\text { beaches and dunes; coastal scrub; wetlands; } \\
\text { riparian vegetation and streams }\end{array}$ \\
\hline Meili Snow Mountains, China & 96,000 & $\begin{array}{l}\text { High gradient streams; temperate mid-montane } \\
\text { coniferous broad-leaved mixed forest; } \\
\text { sclerophyllous evergreen broad-leaved oak forest; } \\
\text { alpine mosaic; gold-temperate coniferous forest }\end{array}$ \\
\hline $\begin{array}{l}\text { Moses Coulee Arid Lands, } \\
\text { Washington, USA }\end{array}$ & 4 million & Shrub steppe \\
\hline Mount Hamilton, California, USA & 647,000 & $\begin{array}{l}\text { Oak woodlands; grasslands; riparian systems; } \\
\text { serpentine systems; sag ponds and seasonal } \\
\text { wetlands }\end{array}$ \\
\hline Nevada and Utah Mountains, USA & 477,000 & $\begin{array}{l}\text { Montane riparian; aspen; wet meadows; mountain } \\
\text { and Wyoming big sagebrush; mountain mahogany } \\
\text { and pinyon-juniper woodlands; black and low } \\
\text { sagebrush }\end{array}$ \\
\hline Northern Reefs, Palau & 33,700 & Coral reefs \\
\hline $\begin{array}{l}\text { Tallgrass Aspen Parkland, } \\
\text { Minnesota, USA }\end{array}$ & 3.1 million & $\begin{array}{l}\text { Open prairies and savannahs; aspen forests; } \\
\text { wetlands }\end{array}$ \\
\hline $\begin{array}{l}\text { Western Arctic, Alaska, USA } \\
\text { and Canada }\end{array}$ & 207 million & Nearshore and offshore marine; boreal forest \\
\hline Yucatan Peninsula, Mexico & 19 million & Tropical dry and moist forest; sand dunes; coral reef \\
\hline
\end{tabular}


Table 2 Methodology for incorporating potential climate impacts into conservation strategies for conservation projects at any scale (TNC 2009)

\begin{tabular}{|c|c|c|}
\hline Step & Explanation & Example: Moses Coulee project \\
\hline $\begin{array}{l}\text { 1. Understand the } \\
\text { potential impacts of } \\
\text { climate change }\end{array}$ & $\begin{array}{l}\text { Consider how changing } \\
\text { climatic conditions will } \\
\text { affect essential ecosystem } \\
\text { features or their } \\
\text { components, including } \\
\text { representative habitats, } \\
\text { select species and } \\
\text { ecological processes. }\end{array}$ & $\begin{array}{l}\text { Climate models predict that the } \\
\text { shrub-steppe habitat in Eastern } \\
\text { Washington, USA will experience } \\
\text { increases in temperature and } \\
\text { altered precipitation patterns. }\end{array}$ \\
\hline $\begin{array}{l}\text { 2. Formulate specific } \\
\text { ecological "hypotheses } \\
\text { of change" }\end{array}$ & $\begin{array}{l}\text { Explore how climate change } \\
\text { will specifically impact the } \\
\text { selected ecosystem features } \\
\text { by developing statements } \\
\text { that detail the system's } \\
\text { ecological vulnerability. }\end{array}$ & $\begin{array}{l}\text { A } 2-3^{\circ} \mathrm{C} \text { rise in annual temperature } \\
\text { coupled with a } 10-30 \% \text { decrease in } \\
\text { summer rainfall and a 5-10\% } \\
\text { increase in winter precipitation will } \\
\text { lead to a greater frequency and } \\
\text { intensity of wildfires, which create } \\
\text { openings for expansion of invasive } \\
\text { cheatgrass, and increased spring } \\
\text { productivity of cheatgrass, } \\
\text { resulting in the decreased cover of } \\
\text { key native shrubs and } \\
\text { bunchgrasses. }\end{array}$ \\
\hline $\begin{array}{l}\text { 3. Explore potential } \\
\text { human responses to } \\
\text { climate change }\end{array}$ & $\begin{array}{l}\text { Identify the likely human } \\
\text { responses to climate change } \\
\text { that may affect the viability } \\
\text { and integrity of the focal } \\
\text { ecosystems and species. In } \\
\text { many cases, the human } \\
\text { response to climate change } \\
\text { may have a greater impact } \\
\text { than direct effects. }\end{array}$ & $\begin{array}{l}\text { Efforts to reduce } \mathrm{CO}_{2} \text { emissions will } \\
\text { result in alternative energy } \\
\text { infrastructure development (wind, } \\
\text { solar, hydropower, biofuels), } \\
\text { leading to a reduction in shrub- } \\
\text { steppe habitat area and decreased } \\
\text { connectivity among remaining core } \\
\text { habitat. }\end{array}$ \\
\hline $\begin{array}{l}\text { 4. Determine which } \\
\text { climate-induced threats } \\
\text { are MOST critical to } \\
\text { address }\end{array}$ & $\begin{array}{l}\text { Use the potential impacts and } \\
\text { human responses from } \\
\text { previous steps, with an } \\
\text { analysis of how current } \\
\text { threats will be exacerbated, } \\
\text { to select the most critical } \\
1-3 \text { threats across the } \\
\text { project area. }\end{array}$ & $\begin{array}{l}\text { In the shrub-steppe, the most critical } \\
\text { climate-induced threats are } \\
\text { invasive cheatgrass expansion and } \\
\text { habitat conversion for alternative } \\
\text { energy development. }\end{array}$ \\
\hline $\begin{array}{l}\text { 5. Evaluate if potential } \\
\text { climate impacts } \\
\text { fundamentally change } \\
\text { the project }\end{array}$ & $\begin{array}{l}\text { Review the critical threats to } \\
\text { assess if any of the project's } \\
\text { ecosystems or species will } \\
\text { no longer be viable or } \\
\text { feasibly restorable. Adjust } \\
\text { or modify focus or scope as } \\
\text { necessary. }\end{array}$ & $\begin{array}{l}\text { One of the focal species, the sage } \\
\text { grouse, is currently thought to have } \\
\text { insufficient habitat and low } \\
\text { population numbers. With } \\
\text { additional habitat loss predicted } \\
\text { due to climate change, this species } \\
\text { may have insufficient habitat for } \\
\text { long-term persistence. Rather than } \\
\text { eliminate sage grouse as a focal } \\
\text { species completely, the emphasis } \\
\text { will be shifted to further highlight } \\
\text { the importance of the shrub-steppe } \\
\text { ecosystem. The sage grouse will be } \\
\text { captured, though not completely, } \\
\text { by shrub-steppe ecosystem } \\
\text { strategies. }\end{array}$ \\
\hline
\end{tabular}


Table 2 continued

\begin{tabular}{|c|c|c|}
\hline Step & Explanation & Example: Moses Coulee project \\
\hline $\begin{array}{l}\text { 6. Develop adaptation } \\
\text { strategies and evaluate } \\
\text { their feasibility and } \\
\text { cost }\end{array}$ & $\begin{array}{l}\text { Create or update strategies } \\
\text { and their associated } \\
\text { statements of the desired } \\
\text { outcomes to address the } \\
\text { effects of the most } \\
\text { significant climate impacts } \\
\text { and human responses on the } \\
\text { project's ecosystems and } \\
\text { species. Use a feasibility, } \\
\text { cost, and benefits analysis } \\
\text { to prioritize adaptation } \\
\text { strategies for } \\
\text { implementation. }\end{array}$ & $\begin{array}{l}\text { Significantly ramp up and prioritize } \\
\text { the existing project strategy to } \\
\text { restore native shrub-steppe habitat } \\
\text { by removing invasive cheatgrass } \\
\text { and limiting its expansion. This } \\
\text { includes requiring treatment of } \\
\text { larger areas and improved fire } \\
\text { management. } \\
\text { A new strategy that emerged was to } \\
\text { minimize the fragmentation of } \\
\text { shrub-steppe habitat from } \\
\text { renewable energy development. } \\
\text { This strategy includes influencing } \\
\text { infrastructure siting and developing } \\
\text { a mitigation fund and will be } \\
\text { critical for maintaining habitat } \\
\text { connectivity and long-term } \\
\text { resilience. }\end{array}$ \\
\hline $\begin{array}{l}\text { 7. Develop measures, } \\
\text { implement, adapt } \\
\text { and learn }\end{array}$ & $\begin{array}{l}\text { Following an adaptive } \\
\text { management approach, } \\
\text { develop measures and } \\
\text { monitoring for the climate } \\
\text { adaptation strategies. } \\
\text { Measure implementation } \\
\text { outcomes to improve } \\
\text { strategies and learn over } \\
\text { time. If important, monitor } \\
\text { selected critical } \\
\text { components of the } \\
\text { ecosystems and species to } \\
\text { understand how climate } \\
\text { change is playing out. }\end{array}$ & $\begin{array}{l}\text { Measuring progress and adapting } \\
\text { will require monitoring shrub- } \\
\text { steppe status, cheatgrass, and } \\
\text { alternative energy development. } \\
\text { We will emphasize measures of } \\
\text { ecosystem integrity that were } \\
\text { selected as sensitive to climate } \\
\text { factors to assess the impacts of } \\
\text { change directly to habitats. We will } \\
\text { monitor the success of cheatgrass } \\
\text { abatement as well as the plant's } \\
\text { response to changing climate } \\
\text { conditions to evaluate future } \\
\text { control needs. We will develop } \\
\text { intermediate measures of progress } \\
\text { toward favorable renewable energy } \\
\text { development that will allow us to } \\
\text { adapt this strategy following } \\
\text { implementation. }\end{array}$ \\
\hline
\end{tabular}

Examples for each step are from the Moses Coulee Arid Lands project in Eastern Washington, USA (TNC 2007)

is now TNC's working methodology for adapting a conservation project to climate change (TNC 2009).

Each of the 20 project teams documented their work, recording and reporting information about project location and size, focal ecosystems and species, likely climate impacts, and their adaptation strategies. This information is presented in detail in Supplementary Tables 1 and 2 available online. We used this information to compile summary data and to draw general conclusions and insights about the emerging practice of climate adaptation. Whenever possible, we summarized data and attributions reported directly by project teams, e.g., whether actions were new or adjusted from previous strategies, and cost estimates for adaptation strategies. In other cases, we classified attributes of the climate impacts and adaptation strategies based on our interpretation of narrative information provided by project teams. 


\section{Results and discussion}

Adaptation strategies were developed for 20 large-scale conservation projects from North America, Central America, South America, Asia, and the Pacific Islands (Table 1). Projects' areas ranged from 24,000 hectares (Chongming Dongtan Estuary, China) to more than 200 million hectares (Western Arctic, Alaska, USA and Canada). Projects spanned a diversity of habitats from large marine systems to coastal estuaries, lakes and rivers, forests, grasslands, aridlands, and montane and alpine ecosystems. While there was an emphasis on habitats and ecosystems in this analysis, six projects also targeted one or more individual species when considering climate impacts or developing adaptation strategies.

We report on three groups of findings from this effort: (1) the character of specific climate change impacts identified by the project teams (i.e., Table 2, Step 2-Formulate specific ecological "hypotheses of change"); (2) anticipated changes to the projects' focal ecosystems and species as a result of these collective impacts (i.e., Table 2, Step 5Evaluate if potential climate impacts fundamentally change the project); and (3) the objectives and actions of climate adaptation strategies to address the potential impacts (i.e., Table 2, Step 6-Develop adaptation strategies and evaluate their feasibility and cost).

Climate change impacts

Project teams identified 139 potential climate change impacts that are likely to affect ecosystems or species in their project area (See Supplementary Table 1). For example, the project team working on the Altamaha-Ogeechee Estuarine Complex identified sea-level rise as a potential cause of coastal habitat loss, and the project team for the Tallgrass Aspen Parkland identified increasing summer temperatures as a potential cause of moose mortality because of heat stress. On average, project teams identified between five and six climate impacts to their project; the minimum was three (Altamaha-Ogeechee Estuarine Complex, USA) and maximum was eight (Atitlán Watershed, Guatemala and Atlantic Forest, Brazil). We classified each of these potential impacts into one or more of a dozen logical categories (Table 3). We also classified them according to the underlying climate factor (e.g., temperature change, precipitation change) (Table 4). Some potential impacts

Table 3 Classification of climate change impacts for 20 conservation projects

\begin{tabular}{lc}
\hline Potential climate impact & $\begin{array}{l}\text { Number } \\
\text { of impacts }\end{array}$ \\
\hline Habitat loss/extent of habitat decrease & 30 \\
Hydrologic regime & 27 \\
Altered species composition & 20 \\
Habitat conditions (integrity/viability) & 18 \\
Water availability & 18 \\
Growing/mating season & 14 \\
Pests and invasives & 11 \\
Fire regime & 10 \\
Food web/trophic level disruptions & 8 \\
Shift in geographic space of habitat & 8 \\
Direct impact on species survival & 7 \\
Fragmentation & 5 \\
Total & 176 \\
\hline
\end{tabular}


Table 4 Classification of climate factors that are driving expected climate impacts for 20 conservation projects

Climate factors leading to impacts

Changes in temperature

Changes in precipitation quantity or timing

Sea-level rise

Increased sea temperature

Ocean acidification

Extreme storm events

Other factors $^{\mathrm{a}}$

Total

Number of impacts

68
61
24
17
4
6
6
186

The total number of climate factors is larger than the number of climate impacts because some impacts are expected to be caused by a combination of climate change factors such as temperature and precipitation or sea level rise and warming ocean temperatures

a Other factors included $\mathrm{CO}_{2}$ fertilization and human responses to climate change such as mitigation policies or engineered adaptation responses

were appropriately placed into more than one category and so the total number of classified impacts was 176 and the total number of classified climate factors was 186. An example of such a dual impact was warmer, drier conditions in the Atlantic Forests of Brazil leading to increased fire frequency and associated habitat degradation-we classified the impact as pertaining to both fire regime and habitat loss, and the climate factor as both change in temperature and change in precipitation.

Habitat loss and changes in habitat conditions were the most and fourth-most cited climate impacts, respectively, constituting 48 (27\%) of all climate impacts identified by project teams (Table 3). For example, rising temperatures were expected to diminish sea ice habitat in the Arctic and cause coral die-backs, and sea-level rise was expected to inundate coastal habitats. Changes to hydrologic regimes was the second-most cited climate impact, identified 27 times (15\%). The least cited climate impact was habitat fragmentation (only 5 citations, $3 \%$ ).

Among the 20 projects, approximately three-quarters of anticipated climate impacts are expected to manifest in ways that are exacerbations of traditional threats-e.g., habitat loss and degradation, altered fire or hydrologic regimes. Novel impacts included shifting ranges (e.g., increased semi-deciduous forest cover in the Atlantic Forest project due to enhanced dryness), food web disruptions (e.g., delayed insect emergence in the Central Appalachians with consequences for wildlife), and changes in life history timing such as reproductive season (e.g., changes in recruitment rates of giant clams in the Northern Reefs of Palau due to an increase in ocean acidification).

In terms of underlying climate factors, temperature changes, including warmer ocean temperatures, were the dominant driver of 85 of the potential climate impacts $(46 \%)$ (Table 4). Precipitation changes and sea level rise were cited $61(33 \%)$ and $24(13 \%)$ times, respectively. The least cited climate factor was ocean acidification (4 citations, $2 \%$ ).

The predominance of temperature-mediated climate impacts is not especially surprising, but it does reinforce the importance of this fundamental environmental variable. Changing air and sea temperatures are the best documented climate changes and among the most pervasive. As scientific uncertainty about the direction and magnitude of precipitation changes is reduced, we would expect the relative importance of this climate variable to increase. Likewise with sea-level rise and ocean acidification, both of which will likely 
continue and perhaps accelerate, but about which the conservation implications are only beginning to be understood.

The similarities of expected climate impacts to 'conventional' threats raise the possibility that traditional conservation interventions might apply. For example, fire management practices and habitat restoration strategies would remain relevant for restoring appropriate fire regimes and compensating for habitat loss, respectively. However, the magnitude and direction of climate impacts could be different than conventional threats and may require modification of specific actions. For example, climate change could increase hydrologic variability (i.e., more flood events) whereas dams generally reduce such variability. Both affect biodiversity by altering hydrologic regimes, but each would prompt different strategies to compensate for anticipated increases or decreases in variability.

The nature of climate impacts could also prompt conventional conservation strategies to be deployed for different purposes. Corridors have commonly been used as a strategy to reconnect isolated habitat patches and to restore gene flow. Increasing connectivity is also frequently recommended as a core adaptation strategy (Heller and Zavaleta 2009). Our 20 projects suggest that the value of connectivity for climate adaptation is less about compensating for habitat fragmentation, and more about facilitating climate-induced changes in species' distributions. Thinking about connectivity this way creates a different motive, and possibly leads to different tactics for corridor design in a changing climate (Krosby et al. 2010).

Anticipated changes to focal ecosystems and species

The 20 project teams evaluated potential climate impacts to 75 ecosystems and species. Twelve projects out of $20(60 \%)$ indicated that at least one focal ecosystem or species

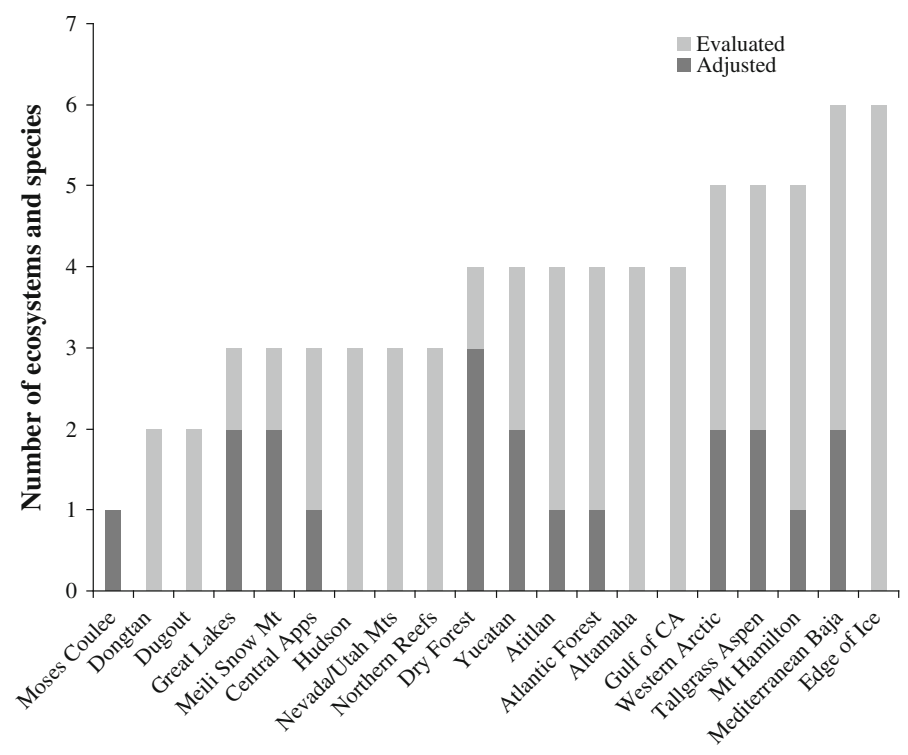

Conservation Projects

Fig. 1 Total number of focal ecosystems and species per conservation project evaluated and number of focal ecosystems and species per conservation project adjusted due to climate change. Project details can be found in Table 1 
(or the project boundary) would likely need to change (Fig. 1). On average, project experts anticipated a potential change in one-third of the focal ecosystems or species that they evaluated at the workshop. Eight projects (40\%) reported that none of the focal ecosystems or species evaluated at the workshop required adjustment or that more analysis was needed to know if an adjustment was necessary.

Addressing all 75 focal ecosystems and species as a group, 35 (47\%) were thought to be unchanged; 17 (23\%) needed more analysis to determine if adjustments were necessary; 11 (15\%) should likely be adjusted now; $6(8 \%)$ would require a project boundary adjustment to continue to accommodate them; $5(6 \%)$ should no longer be considered in the project area or should be considered elsewhere in the region; and 1 (1\%) new focal ecosystem/ species was identified.

The Western Arctic conservation project in Alaska, USA and Canada illustrates the types of changes to focal ecosystems and species that were anticipated. Following their climate impact analysis, the project team determined no adjustments were needed to conserve the focal species 'barren ground caribou' and 'bowhead whale.' In contrast, to continue to conserve 'ice-dependent marine mammals' the project's scope or boundary would need to significantly change from the current delineation and encompass additional areas where ice might remain under warming scenarios. They also determined that 'benthic fauna' should be dropped because anticipated severe shifts in species composition due to warmer waters were not feasible to address. Finally, the team felt that further analysis was needed for the 'greater and lesser scaup' (e.g., life history, shift in populations) to determine if a major adjustment was needed.

The fact that $40 \%$ of the project teams did not make adjustments to their focal ecosystems and species could reflect a general reluctance of conservation practitioners to "give up on anything." It could also reflect a reality in which conservation options are already constrained such that few modifications are even possible without abandoning a project entirely. Even so, most project teams did indicate numerous modifications of more than half of their focal ecosystems and species. This demonstrates that climate change may necessitate modifications to conservation projects and that conservation practitioners are willing to make appropriate changes when developing adaptation strategies.

\section{Climate adaptation strategies}

In response to potential climate impacts, project teams developed a total of 42 adaptation strategies. Each strategy was designed to address a specific climate impact. Instead of attempting to develop strategies for every possible climate impact, project teams were asked to prioritize one to three climate impacts that they felt were the most important for their projects. Project teams were encouraged to develop adaptation strategies for additional climate impacts at their own discretion.

Each adaptation strategy included an objective and a set of one or more actions designed to intervene in anticipation of a specific climate impact. Teams noted whether these strategies included new or adjusted actions compared to their initial conservation strategies, and estimated approximate costs. For example, one adaptation strategy objective for the Northern Reefs of Palau project was "by 2015, identify and effectively protect all resistant and most resilient coral sites in order to increase probability of retaining coral cover in the face of sea surface temperature increases and acidification." The strategic actions associated with this objective were to: (a) map the most resistant and resilient sites; (b) include special protection of these sites in the management plan; and (c) insure 
Table 5 Classification of adaptation strategies as being focused on resistance to climate change, resilience in the face of climate change, or transformation under climate change

\begin{tabular}{ll}
\hline Objective of adaptation strategies & $\begin{array}{l}\text { Number } \\
\text { of strategies }\end{array}$ \\
\hline Resistance & 22 \\
Resilience & 18 \\
Transformation & 2 \\
Total & 42 \\
\hline
\end{tabular}

\begin{tabular}{lc}
\hline Actions comprised by adaptation strategies & $\begin{array}{l}\text { Number } \\
\text { of strategies }\end{array}$ \\
\hline New & 18 \\
Adjusted & 24 \\
Unchanged & 2 \\
Not indicated & 7 \\
Total & 51 \\
\hline
\end{tabular}

Table 6 Classification of adaptation strategies as including new or adjusted actions

Strategies could include any combination of new, adjusted, or unchanged actions, so tallies in this table add to more than 42 effective enforcement of allowable human activities. This strategy was new to the project and was estimated to cost between $\$ 10,000$ and $\$ 100,000$.

In order to describe and compare general features of these adaptation strategies, we categorized strategies as focusing on resistance, resilience, or transformation (after Heller and Zavaleta 2009) (Table 5), identified which strategies included actions that were new or adjusted from earlier non-climate adapted strategies (Table 6), and categorized specific actions associated with each strategy according to the conservation actions taxonomy promulgated under the Open Standards for the Practice of Conservation (CMP 2007) (Table 7). See Supplementary Table 2 for a complete table of adaptation strategies as defined by project teams, and our classifications of those strategies and actions.

Resistance strategies attempt to maintain the status quo of biodiversity in the face of climate change or other climate-exacerbated threats. Such strategies included compensating for changes in water availability, or rebuilding habitat that might be degraded by climate change. Resilience strategies aim to enhance the ability of ecosystems or species to accommodate disturbances induced or exacerbated by climate change (Holling 1973; Gunderson and Holling 2002; Heller and Zavaleta 2009). Such strategies included protecting refugia, creating corridors to allow for species movement or managing for different age and seral stages that are better adapted to anticipated conditions. Transformation strategies aim at protecting or managing for a novel future state, such as changes in ecosystem types that occur with inundation of coastal land with sea level rise or proactively translocating species beyond current range limits. Under these definitions, for example, the Northern Reefs of Palau project cited above was classified as a resilience strategy because it aims to increase the ability of coral reef ecosystems to persist in the face of warmer temperatures and more acidic water. Some adaptation strategies presented a combination of resistance and resilience objectives or resilience and transformation objectives. As with categorization of climate impacts, we allowed for joint categorization in our tallies.

Of the 42 adaptation strategies developed by the 20 conservation projects, $22(52 \%)$ focused on resistance and $18(45 \%)$ focused on resilience. Two strategies included transformation elements-anticipating the need for new policy mechanisms to protect 
Table 7 Classification of actions prescribed under adaptation strategies

Categorization of adaptation strategy actions

0 . Science and planning

0.1 Scientific research

0.2 Conservation planning

0.3 Priority-setting

0.4 Monitoring

1. Land/water protection

1.1 Site/area protection

1.2 Resource \& habitat protection

2. Land/water management

2.1 Site/area management

2.2 Invasive/problematic species control

2.3 Habitat \& natural process restoration

3. Species management

3.1 Species management

3.2 Species recovery

3.3 Species re-introduction

3.4 Ex-situ conservation

4. Education \& awareness

4.1 Formal education

4.2 Training

4.3 Awareness \& communications

5. Law \& policy

5.1 Legislation

5.2 Policies \& regulations

5.3 Private sector standards \& codes

5.4 Compliance \& enforcement

6. Livelihood, economic \& other incentives

6.1 Linked enterprises \& livelihood alternatives

6.2 Substitution

6.3 Market forces

6.4 Conservation payments

6.5 Non-monetary values

7. External capacity building

7.1 Institutional \& civil society development

7.2 Alliance \& partnership development

7.3 Conservation finance

Indeterminate

Total

Actions were categorized according to the conservation actions taxonomy promulgated under the Open Standards for the Practice of Conservation (CMP 2007). We added five action categories to a standard taxonomy (CMP 2007) to accommodate calls for scientific research and conservation planning as part of adaptation strategies. Actions were assigned to the category that we judged to best describe what project teams proposed to do
Number of actions

25

4

9

5

10

9

1

26

6

4

16

2

2

0

0

0

0

0

0

25

3

13

6

3

2

2

2

3

1

1

12

3
1
112
anomy promulgated under the Open
and conservation planning as part of
judged to best describe what project


shallow lake bottom habitats that would potentially be exposed as lake levels drop in the Great Lakes, and securing abandoned agricultural land to allow for climate-mediated migration of wetlands (Table 5).

The predominance of resistance strategies contrasts with the literature about climate change and biodiversity management in which resilience strategies were recommended more than twice as often as resistance strategies (Heller and Zavaleta 2009). One possible explanation for this difference is the inherent tendency of conservationists to try to keep things as they are, such that resistance strategies may be preferred whenever possible. Another is that ecosystems and species already at risk may not have the capacity to accommodate further change. In such cases, resilience may sound good in principle, but may not be a practical or possible option in practice to maintain these ecosystems and species.

Regardless of the type of adaptation strategy adopted, climate adaptation strategies consistently departed from business-as-usual. Eighteen (43\%) of the strategies the projects developed included entirely new actions not previously considered as part of the original conservation plan. Twenty-four (57\%) of the strategies included actions that were adjustments of the original strategies. Only two strategies retained an existing action without modification, but still included new or adjusted actions. Indications were not recorded for 7 strategies (17\%) (Table 6). These findings provide strong evidence that considerations of climate change motivate substantive changes in conservation strategies. They also suggest that conservation projects that ignore climate change could be compromised because they are not appropriately tailored to their potential future situation.

\section{Adaptation actions}

To better understand the nature of the actions to be taken under adaptation strategies, we categorized actions according to a standard taxonomy of 21 conservation actions (Salafsky et al. 2008). Some project teams included scientific research and conservation planning actions that did not have an obvious place in the taxonomy. To account for those, we added an additional set of actions to the taxonomy under the general header of "Science and Planning" including scientific research, conservation planning, priority-setting, and monitoring. Most actions were easily assigned to a specific action classification, but a couple could only be assigned to general heading categories.

Adaptation strategies comprised a diversity of actions. Every major category of the action taxonomy was represented except Education and Awareness. Actions to restore habitat and natural processes like hydrologic and fire regimes, and to influence government policies and recommendations were dominant, cited 16 and 13 times, respectively. When actions are viewed in relation to higher-level headings within the taxonomy, science and planning are frequently cited, as are actions related to land and water protection; livelihood, economics \& other incentives; and external capacity building (Table 7).

The predominance of habitat restoration and policy actions may be a reflection of The Nature Conservancy's core competencies - teams may have been predisposed to pursue actions with which they were most familiar and skilled. That notwithstanding, projects prescribed a diversity of actions within their strategies, demonstrating that the challenge of climate adaptation does not have a single, simple solution. Adaptation requires a carefully selected combination of actions to achieve desired outcomes. Just as the specific impacts are varied, so too are the actions that should be taken.

The fact that several project teams indicated a need for more planning and research underscores the need for rigorous science to answer key questions and resolve key 
Table 8 Estimates of the cost of adaptation strategies

Some teams reported cost estimates for entire strategies; others estimated for each action separately. We aggregated all cost estimates by strategy, using the same logarithmic scale categories used by project teams

\begin{tabular}{lc}
\hline Total cost of strategy & $\begin{array}{l}\text { Number } \\
\text { of strategies }\end{array}$ \\
\hline$\geq \$ 1,000,000$ & 8 \\
$\geq \$ 100,000$ & 9 \\
$\geq \$ 10,000$ & 13 \\
$<\$ 10,000$ & 2 \\
Not estimated & 10 \\
Total & 42 \\
\hline
\end{tabular}

uncertainties. This is understandable in this early phase of adaptation strategy development, but project teams must avoid "analysis paralysis" or letting uncertainty be an excuse for delaying reasonable actions.

\section{Costs of adaptation strategies}

A possible concern about modifying conservation strategies to account for climate change is that adaptation strategies may be too costly. To assess this concern, we summarized categorical cost estimates provided by project teams. Teams estimated cost as Low $(<\$ 10,000)$, Medium $(\geq \$ 10,000,<\$ 100,000)$, High $(\geq \$ 100,000,<\$ 1,000,000)$ and Very High $(\geq \$ 1,000,000)$. Some teams estimated costs for entire strategies; some reported estimates for each action. In the latter cases, we summed the action-wise cost estimates and recategorized a cost estimate for the entire strategy. Cost estimates were not reported for ten strategies.

Nearly half of the adaptation strategies (15 of 32 strategies for which cost estimates were made) had cost estimates less than $\$ 100,000$. Seventeen strategies were estimated to cost more than $\$ 100,000$ or even $\$ 1,000,000$ (Table 8). Such costs are not inconsequential, but neither are they prohibitively expensive, especially considering the spatial scale of so many of these projects.

\section{Final considerations}

Our learning experiment with 20 projects from around the world highlights three major challenges that need to be addressed by institutions engaged with adapting and redesigning conservation projects to climate change. First, adapting to climate change requires clearly linking an explicitly stated expectation about how climate change may affect species, ecosystems, or even people, to clear objectives and actions that can address those climate impacts. The structured process we used for developing adaptation strategies was intended to create clear logic leading from climate impacts to adaptation strategies. For example, the Great Lakes project concluded that increasing air temperature will lead to increased evapotranspiration and a lowering of average seasonal lake levels by $0.5-1.5 \mathrm{~m}$. This in turn will expose shoreline substrate, creating new ground for invasive species and for human development. The project team determined that a key adaptation strategy is to develop policy to ensure that any new exposed bottom land (including wetlands and unvegetated nearshore) is protected from development. Adaptive monitoring could include tracking lake levels, exposed substrate, and the progress of actions toward policy development.

Second, the outcome from our 20-project sample suggests that for the majority of conservation projects, climate impacts will necessitate significant changes, such as 
changing the project area, reprioritizing or even abandoning some ecosystems or species, revising conservation goals for ecosystems or species, or modifying management actions or interventions. Although not surprising, these results constitute early evidence of how climate change could specifically impact a number of existing conservation projects. Ideally, all conservation projects should evaluate potential adjustments for climate change. Incorporating climate considerations into conservation projects must become the new business as usual, although the institutional mechanisms for achieving this are not yet in place. Key enabling conditions include having an explicit step-by-step methodology, cultivating the ability to take reasoned action despite uncertainty, identifying 'no-regrets' strategies that hedge bets against major uncertainties, and further embracing an adaptive conservation paradigm.

Finally, although all of our projects adjusted their strategies in some way, there was a general cautiousness reflected by the fact that only two projects pursued a transformative direction. Leading edge thinking calls for new frameworks for conservation that embrace unavoidable and accelerating change (e.g., Harris et al. 2006; Kareiva and Marvier 2007). For example, Harris et al. (2006, p. 175) states about ecological restoration that:

To this complexity and lack of understanding, we now have to add the fact that environments are changing, and the rate of change is unprecedented. The past is no longer a prescriptive guide for what might happen in the future. There is a large component of ecological restoration that still places considerable value on past ecosystems and seeks to restore the system's characteristics to its past state. Valuing the past when the past is not an accurate indicator for the future may fulfill a nostalgic need but may ultimately be counterproductive in terms of achieving realistic and lasting restoration outcomes.

Our results indicate a significant gap between theory and practice-understandable for the early stages of climate adaptation. We hypothesize that climate adaptation in reality may require a greater preponderance of transformative strategies, and that scientists and institutions should accelerate exploring such approaches to define and develop the next generation of conservation strategies.

Acknowledgements We would like to express appreciation to everyone involved in the climate adaptation process and workshop, especially the 20 conservation project teams and class facilitators and knowledge managers who contributed their ideas and experiences to the collective wisdom presented in this paper. Appreciation goes to Kristin Richards Betz and Anne Wallach Thomas for building and maintaining TNC's climate adaptation website (http://conserveonline.org/workspaces/climateadaptation) before, during, and after the workshop. This paper also benefitted from the input of our colleagues Peter Kareiva, Stacey Solie, Karen Lombard, and Dan Majka, and all the participants of the January 2010 TNC writing workshop in Tucson, Arizona.

Open Access This article is distributed under the terms of the Creative Commons Attribution Noncommercial License which permits any noncommercial use, distribution, and reproduction in any medium, provided the original author(s) and source are credited.

\section{References}

Araujo MB, Rahbek C (2006) How does climate change affect biodiversity? Science 313:1396-1397 Bierwagen BG, Thomas R, Kane A (2008) Capacity of management plans for aquatic invasive species to integrate climate change. Conserv Biol 22:568-574 
CMP (2007) Open standards for the practice of conservation. Version 2.0. http://www.conservationmea sures.org/CMP/Site_Docs/CMP_Open_Standards_Version_2.0.pdf. Cited 22 Apr 2010

Dunwiddie PW, Hall SA, Ingraham MW, Bakker JD, Nelson KS, Fuller R, Gray E (2009) Rethinking conservation practice in light of climate change. Ecol Restor 27:320-329

Galatowitsch S, Frelich L, Phillips-Mao L (2009) Regional climate change adaptation strategies for biodiversity conservation in a midcontinental region of North America. Biol Conserv 142:2012-2022

Girvetz EH, Zganjar C, Raber GT, Maurer EP, Kareiva P, Lawler JJ (2009) Applied climate-change analysis: the Climate Wizard tool. PLoS One 4. doi:10.1371/journal.pone.0008320

Gunderson LH, Holling CS (eds) (2002) Panarchy: understanding transformations in human and natural systems. Island Press, Washington

Hannah L, Midgley GF, Lovejoy T, Bond WJ, Bush M, Lovett JC, Scott D, Woodward FI (2002a) Conservation of biodiversity in a changing climate. Conserv Biol 16:264-268

Hannah L, Midgley GF, Millar D (2002b) Climate change-integrated conservation strategies. Glob Ecol Biogeogr 11:485-495

Harris JA, Hobbs RJ, Higgs E, Aronson J (2006) Ecological restoration and global climate change. Restor Ecol 14:170-176

Heller NE, Zavaleta ES (2009) Biodiversity management in the face of climate change: a review of 22 years of recommendations. Biol Conserv 142:14-32

Holling CS (1973) Resilience and stability of ecological systems. Annu Rev Ecol Syst 4:1-23

Hulme PE (2005) Adapting to climate change: is there scope for ecological management in the face of a global threat? J Appl Ecol 42:784-794

Hunter M, Dinerstein E, Hoekstra J, Lindenmayer D (2010) Conserving biodiversity in the face of climate change: a call to action. Conserv Biol 24:1169-1171

Kareiva P, Marvier M (2007) Conservation for the people. Sci Am 297:50-57

Kareiva P, Enquist C, Johnson A, Julius SH, Lawler J, Petersen B, Pitelka L, Shaw R, West J (2008) Synthesis and conclusions, Chap 9. In: Julius SH, West JM (eds) Preliminary review of adaptation options for climate-sensitive ecosystems and resources. A report by the U.S. climate change science program and the subcommittee on global change research. U.S. EPA, Washington, DC

Krosby M, Tewksbury J, Haddad NM, Hoekstra J (2010) Ecological connectivity for a changing climate. Conserv Biol. doi:10.1111/j.1523-1739.2010.01585.x

Lawler JJ (2009) Climate change adaptation strategies for resource management and conservation planning. Year Ecol Conserv Biol, NY Acad Sci 1162:79-98

Lawler JJ, Tear T, Pyke CR, Shaw R, Gonzalez P, Kareiva P, Hansen L, Hannah L, Klausmeyer K, Aldous A, Bienz C, Pearsall S (2009) Resource management in a changing and uncertain climate. Front Ecol Environ 7. doi:10.1890/070146

Mawdsley JR, O’Malley R, Ojima DS (2009) A review of climate-change adaptation strategies for wildlife management of biodiversity conservation. Conserv Biol 23:1080-1089

McClanahan TR, Cinner J, Maina J, Graham NAJ, Daw TM, Stead SM, Wamukota A, Brown K, Ateweberhan M, Venus V, Polunin NVC (2008) Conservation action in a changing climate. Conserv Lett 1:53-59

Orr DW (2008) Land use and climate change. Conserv Biol 22:1372-1374

Parmesan C (2006) Ecological and evolutionary responses to recent climate change. Annu Rev Ecol Evol Syst 37:637-669

Parry ML, Canziani OF, Palutikof JP, van der Linden PJ, Hanson CE (eds) (2007) Climate change 2007: impacts, adaptation and vulnerability, contribution of working group II to the fourth assessment report of the Intergovernmental Panel on Climate Change. Cambridge University Press, Cambridge, $\mathrm{UK}$

Peters RL, Myers JP (1991) Preserving biodiversity in a changing climate. Issues Sci Technol 8:66-72

Root TL, Schneider SH (2006) Conservation and climate change: the challenges ahead. Conserv Biol 20:706-708

Sala OE, Chapin FS III, Armesto JJ, Berlow E, Bloomfield J, Dirzo R, Huber-Sanwald E, Huenneke LF, Jackson JB, Kinzig A, Leemans R, Lodge DM, Mooney HA, Oesterheld M, Poff NL, Sykes MT, Walker BH, Walker M, Wall DH (2000) Biodiversity-global biodiversity scenarios for the year 2100 . Science 287:1770-1774

Salafsky N, Salzer D, Stattersfield AJ, Hilton-Taylor C, Neugarten R, Butchart SHM, Collen B, Cox N, Master LL, O'Connor S, Wilkie D (2008) A standard lexicon for biodiversity conservation: unified classifications of threats and actions. Conserv Biol 22:897-911. doi:10.1111/j.1523-1739.2008.00937.x

Scott D, Lemieux C (2005) Climate change and protected area policy and planning in Canada. For Chron 81:696-703 
TNC (2007) Conservation action planning report for the Moses Coulee Conservation Area. Seattle, Washington

TNC (2009) Conservation action planning guidelines for developing strategies in the face of climate change. http://conserveonline.org/workspaces/climateadaptation/documents/climate-clinic/documents/climatechange-project-level-guidance. Cited 22 Apr 2010

Tompkins EL, Adger WN (2004) Does adaptive management of natural resources enhance resilience to climate change? Ecol Soc 9. http://www.ecologyandsociety.org/vol9/iss2/art10/. Cited 22 Apr 2010

Vos CC, Berry P, Opdam P, Baveco H, Nijhof B, O'Hanley J, Bell C, Kuipers H (2008) Adapting landscapes to climate change: examples of climate-proof ecosystem networks and priority adaptation zones. J Appl Ecol 45:1722-1731

Welch D (2005) What should protected area managers do in the face of climate change? George Wright Forum 22:75-93 